\title{
Społeczna Przyroda Nowych Artystycznych kierunków w Miejskim Środowisku
}

\section{Social Nature - New Artistic Directions in the Urban Environment}

\section{Streszczenie}

Trendy globalizacji stymulowały pojawianie się zjawisk mających na celu wyrażanie osobowości. Należy zauważyć, że w większości przypadków główne wyrażenia tych idei były nieformalne, w biednych dzielnicach Ameryki pojawiła się „sztuka uliczna” (Street Art), a teraz istnieje kilka rodzajów nieformalnej sztuki, dostępnej dla wielu. Ponadto sztuka, która wyrosła z nieformalnych trendów, to dziś także reklama na frontach budynków, wystawy w galeriach, druk na odzieży.

Słowa kluczowe: nowe kierunki artystyczne, globalizacja, sztuka ulicy

\section{Abstract}

Globalization trends have stimulated the emergence of protest phenomena aimed at expressing personality. It should be noted that in most cases, the main expressions of the idea were informal - there were the same phenomena as street art (it could be Street Art) in the poorer districts of America, and now there are several types of informal art that are seen by a large number of people. Besides this art, which grew out of informal trends, has become today in advertising on the fronts of buildings, exhibitions in galleries, and printing on clothing.

Keywords: new artistic trends, globalization, street art 


\section{WSTĘP}

Powodem gwałtownego rozprzestrzeniania się sztuki ulicznej jako rodzaju sztuki nieformalnej był sprzeciw wobec zjawiska globalizacji i kryzysu wartości w społeczeństwie, choć w tym samym czasie globalizacja sprzyjała bliskim kontaktom między ulicznymi artystami z różnych krajów. Z biegiem czasu sztuka uliczna stała się wyrazem artystycznych trendów i własnej filozofii. Widać podobieństwa do minionego ruchu hipisowskiego - to artyści z różnych krajów, którzy podczas komunikowania się ze sobą starają się unikać tematów politycznych. Działa tzw. social networking, gdzie artyści zapraszają się wzajemnie do wspólnych działań twórczych, przy czym strona przyjmująca musi zapewnić gościowi bezpłatne zakwaterowanie i posiłki.

Według światowego doświadczenia próby zakazu sztuki ulicznej tylko prowokowały jej rozprzestrzenianie się, dlatego też w wielu krajach świata została ona zalegalizowana poprzez prawne uregulowania do lokowania artystów. sztuka nieformalna, której przedstawicielami są głównie młodzi ludzie, stała się również dochodowym zjawiskiem. Zatem zjawisko sztuki nieformalnej powinno być analizowane nierozerwalnie, razem z nowym rodzajem artystycznej struktury wielofunkcyjnej - klastra artystycznego.

\section{POWODY POJAWIENIA SIĘ KLASTRA SZTUKI JAKO CAŁKOWICIE NOWEGO TYPU STRUKTURY WIELOFUNKCYJNEJ}

Pod koniec XX wieku oraz na początku XXI wieku popularność zyskuje rodzaj przestrzeni zwanej „klastrem sztuki”. Chociaż klastry zaczęły pojawiać się stosunkowo niedawno, pomysł stworzenia „drugiego życia, dla nierentownych przedsiębiorstw przemysłowych pojawił się znacznie wcześniej. W latach czterdziestych na Manhattanie powstały tzw. lofty. Jednak w tamtym czasie przewidywano przekształcenie przedsiębiorstw przemysłowych w deweloperów mieszkaniowych i studyjnych, biorąc pod uwagę gwałtowny wzrost cen gruntów w centralnych częściach miasta. Dawne tereny przemysłowe, gdzie koszt wynajmu lokalu był niski, a lokale mogły być wykorzystane do dowolnej funkcji i gromadziły artystów wyrażających różne kierunki artystyczne - powoli zanikały.

Manhattan stał się miejscem, w którym połączono sztukę i biznes. Jest tam miejsce na przestrzeń wystawienniczą, teatr, audytorium na seminaria i szkolenia biznesowe itp. Jednocześnie klaster działa jako holistyczna instytucja, w której każdy komponent działa według wspólnej idei i jest częścią jednej organizacji strukturalnej. Inną cechą współczesnych klastrów sztuki jest obecność przekształconych przestrzeni do organizowania różnych wydarzeń. W klastrze mieszczą się placówki gastronomiczne różnych typów i hotele przeznaczone dla osób przyjeżdżających na różne imprezy z innych miast. 
Przekształcenie dawnych przedsiębiorstw przemysłowych w klaster sztuki zakłada, że najważniejszą rzeczą jest funkcja artystyczna w różnych wariantach, co można zobaczyć na przykładzie:

1. OFF Piotrkowska ( $z$ dawnej fabryki tkanin bawełnianych Franciszka Ramsa - Łódź): muzyka, fotografia, grafika i architektura, catering, wydarzenia kulturalne, warsztaty, galeria/przestrzeń wystawiennicza/muzeum. Branża lekka -szeroki zakres funkcji.

2. Schiffbau (z dawnej fabryki statków - Zurych): teatr, jedzenie, orientacja na wydarzenia. Z zakładu stoczniowego - ograniczona listę funkcji.

3. Lowenulgeunst (z dawnego browaru - Zurych): galeria/przestrzeń wystawiennicza/muzeum, wydarzenia kulturalne. Branża spożywcza - szeroki zakres funkcji.

4. Mains d’Oeuvres Saint-Quen (z dawnej fabryki części samochodowych - Paryż): teatr, catering, orientacja na wydarzenia, galeria/przestrzeń wystawiennicza/muzeum, taniec, przestrzeń edukacyjna, muzyka, przestrzeń biznesowa. Budowa maszyn - szeroka lista funkcji.

5. Fabrika Trzciny (z dawnej fabryki do produkcji marmolady i konserw - Warszawa): galeria/przestrzeń wystawiennicza/muzeum, jedzenie, teatr, orientacja na wydarzenia. Branża spożywcza - szeroki zakres funkcji.

6. Art-fabryka Platforma (z dawnej fabryki jedwabiu Darnytsky - Kijów): przestrzeń edukacyjna, przestrzeń biznesowa, galeria/przestrzeń wystawiennicza/muzeum, orientacja na wydarzenia, żywność, funkcja handlowa. Branża lekka - szeroki zakres funkcji.

7. Fabrika.space (z zamkniętej instalacji do sortowania nasion - Charków): orientacja na zdarzenia, catering, przestrzeń biznesowa. Branża spożywcza - szeroki zakres funkcji.

8. Brotfabrik Wien (z dawnej piekarni - Wiedeń): warsztaty, galeria/przestrzeń wystawiennicza/muzeum, przestrzeń biznesowa, jedzenie, orientacja na wydarzenia. Branża spożywcza - szeroki zakres funkcji.

9. Fabryka sztuki (Art Incubator) (dawna fabryka bawełny w Księżym Młynie - Łódź): teatr, muzyka, przestrzeń edukacyjna, galeria/przestrzeń wystawiennicza/muzeum, przestrzeń biznesowa (inkubator sztuki), imprezy, catering, warsztaty. Branża lekka - szeroki zakres funkcji.

Przedsiębiorstwa przemysłu lekkiego i spożywczego są najbardziej odpowiednie do rewitalizacji w ramach klastrów sztuki o różnej zawartości funkcjonalnej.

Każdy klaster sztuki składa się z pewnej liczby różnych składników funkcjonalnych, które są indywidualnie samowystarczalne, ale tylko razem tworzą klaster - każdy składnik może być w dowolnym momencie zastąpiony przez inny, co żaden sposób nie wpływa na obiekt jako całość (Il. 1).

Biorąc pod uwagę, że klastry sztuki często znajdują się na terenie zamkniętych zakładów przemysłowych i mają dużą powierzchnię, wpływają na środowisko miejskie. Jednym z podstawowych warunków tworzenia klastra sztuki jest jego zdolność do przekształcenia się w ramach funkcji artystycznej (dlatego ograniczona jest lista przedsiębiorstw branż, które to umożliwiają) oraz dostępność komunikacyjna (w większości klastry sztuki znajdują się w pobliżu autostrad, przystanków itp.). 


\section{SZTUKA ULICZNA JAKO ŚRODEK ODDZIAŁYWANIA NA ŚRODOWISKO MIEJSKIE}

Rzeczywistością staje się obecność nietypowych pod względem estetycznym środków artystycznego wyrazu, które jednak od dawna powszechne są w krajach najbardziej rozwiniętych. Przechodząc ulicami Kijowa, można zobaczyć ogromne obrazy na frontach domów - tak zwane "murale”. Jest to dowód, że spontaniczna sztuka uliczna, która w początkowej fazie swojego istnienia była symbolem protestu, stopniowo stała się znakiem czasu, współistniejąc w sposób harmonijny ze strategiami miejskimi i przyczyniając się do modernizacji przestrzeni miejskiej.

Zjawisko sztuki ulicznej, nazywane powszechnie „graffiti”, jest jedną z najbardziej kontrowersyjnych we współczesnym świecie. Sztukę uliczną porównać można do buntu niesfonego dziecka, które wszystkimi sposobami próbuje zwrócić na siebie uwagę, ale podrastając, zaczyna „grać według reguł”: pokazywać swoje obrazy w galeriach, wypuszczać marki odzieży młodzieżowej. Społeczeństwo stopniowo przyzwyczailo się do tego „zbuntowanego dziecka”, którego celem jest utrwalenie wszędzie i w najbardziej ekstrawagancki sposób własnego „ja”. Sztuka uliczna przeszła długą drogę aż do momentu, w którym graffiti uzyskalo pełnoprawny status współczesnej sztuki awangardowej. Obecnie grafiiti często służy propagandzie politycznej - wcześniej, w latach sześćdziesiątych, była jedynie wizualnym środkiem agitacji. Od początku 1961 roku sztuka uliczna i graffiti miały rolę sztuki neformalnej, ale od 1990 roku one uzyskały funkcję przekazu propagandy politycznej. Rola graffiti zawsze wzrastała w czasach zmian politycznych, o czym świadczą doświadczenia ostatnich rewolucji ukraińskich.

Jednocześnie, pomimo że młodzi ludzie pozytywnie postrzegają pojawianie się graffiti i muralów na fasadach, istnieje wielu przeciwników tego zjawiska. Są to głównie osoby starsze, którym sztuka uliczna kojarzy się z nieprzyzwoitymi napisami i jest jedynie niszczeniem murów, a autorzy to młodzi ludzie pochodzący z rodzin z nizin społecznych, często patologicznych.

W krajach Europy Zachodniej i Stanach Zjednoczonych sprzedawcy Coca-Coli, McDonalds, Toyoty, Smirnoffa, sklepów Boxfresh w Covent Garden i MTV zwracają uwagę na neformalnych artystów. Projekty te zyskały popularność dzięki zespołowi TATS CRU w Nowym Jorku. Graffiti rozprzestrzeniło się w branży reklamowej. Potwierdzeniem przekształcenia sztuki ulicznej w sztukę galerii jest to, że w 2006 roku w Muzeum Brooklińskim odbyła się wystawa graffiti, a w 2009 roku 150 artystów zaprezentowało 300 dzieł graffiti w Grand Palace w Paryżu. Geografia takich wystaw pokazuje międzynarodowość fenomenu sztuki ulicznej i wzrost popytu na tę sztukę. Na elewacjach budynków, placach zabaw, we wnętrzach instytucji młodzieżowych, a nawet na ścianach kotłowni i nierentownych przedsięwzięciach możemy oglądać coraz więcej przykładów graffiti. 
Nowa fala rozwoju sztuki ulicznej na Ukrainie powstała w wyniku „rewolucji godności”. Wiadomo, że zmiany polityczne we wszystkich krajach świata doprowadziły do aktywacji tzw. politycznego graffiti. Dziś w Kijowie, Lwowie, Połtawie i wielu dużych miastach istnieje to zjawisko. W większości przypadków takie obrazy są spontaniczne.

Doświadczenie pokazuje, że historia sztuki jako właściwość społeczeństwa zawsze odzwierciedla bieżące i utajone procesy społeczne w społeczeństwie i w wielu przypadkach jest zwiastunem przyszłych zmian. Street Art to ciekawe zjawisko społeczne w czasach ogólnej globalizacji współczesnego społeczeństwa, gdy dana osoba stara się odizolować od globalnej przestrzeni i ukazać swoje własne „ja”. Różne wiekowo grupy ludzi inaczej odnoszą się do powstania sztuki ulicznej (konflikt pokoleń) - ludzie starsi i w średnim wieku, którzy żyli w rzeczywistości socjalistycznej, i młodzież, urodzona w latach niepodległości, chcąca usunąć bariery między Ukrainą a światem zewnętrznym. Dla młodych ludzi sztuka uliczna, graffiti i muralizm stały się częścią ich życia, logicznym sposobem wyrażania siebie.

Pod względem treści ideowych oraz stylistycznych graffiti i muralizm są bliskie innym typom sztuki ulicznej, w których wykorzystywane są postacie, czasem rozumiane tylko przez samego artystę (kamera wideo w ptasim gnieździe, pomalowany na czerwono kosz na śmieci, różne instalacje awangardowe). Wszystkie są połączone wspólnym planem, aby zwrócić uwagę na artystę i jego pracę, podkreślić artystyczną osobowość.

W przeciwieństwie do graffiti muralizmy używają tylko portretów, abstrakcji, wzorów i fabuł. Dopatrzyć się można analogii z pojęcem „supergrafiki” z czasów radzieckich. Ze względu na technikę i sposób wykonania graffiti oraz supergrafiki w architekturze muralizm można uznać za przykład obu tych form wyrazu. Murale można wykonywać na różne sposoby aerozolem w sprayu, za pomocą mozaiki, płytek ceramicznych. Możliwe jest porównanie muralizmu i supergrafiki architektonicznej, ale nie można porównać graffiti tworzonego bez szkicu i spontanicznie, w przypadkowym miejscu, z taką samą pracą Hundertvasera czy Gaudiego. W tym samym czasie muralizm przechodzi przez techniki graficzne.

Różnica polega na wykorzystanych umiejętnościach oraz czasie istnienia murali i graffiti. Graffiti to spontaniczny rodzaj sztuki, w zasadzie jest to wykonywany w stylizowanej, charakterystycznej czcionce „nick” (niezrozumiały dla ogółu społeczeństwa), tworzony na dowolnym pustym planie, szybko. Graffiti jest przede wszystkim znakiem. Dlatego powstaje w najbardziej niebezpiecznych i nietypowych miejscach, takich jak dachy, wieże, mosty itp.

W Europie Zachodniej i USA już dawno zrozumiano, że bezwarunkowy zakaz sztuki ulicznej nie przynosi sukcesu, a zaangażowanie znanych artystów może pomóc ucywilizować ruch sztuki ulicznej i razem z tym tanio i szybko ozdobić mało estetyczne budynki. W wielu przypadkach nastąpiło przekształcenie nierentownych centr biznesowych w młodzieżowe obiekty rozrywki i sztuki młodzieżowej. 


\section{PROPOZYCJE PROJEKTÓW PRZEKSZTAŁCAJĄCE SIĘ W KLASTER SZTUKI DAWNEGO BROWARU RICHERTOWEGO W KIJOWIE}

Na podstawie doświadczeń europejskich przemian, w warunkach braku klastrów sztuki i biorąc pod uwagę konieczność przestrzegania krajowych przepisów dotyczących ochrony zabytków (budynek dawnego browaru Richertowego jest zabytkiem architektury o znaczeniu lokalnym), zaproponowano konkurs na projekt, którym jest stworzenie ośrodka sztuki z możliwośćiu rozwijania kreatywnego potencjału w nowych kierunkach.

Ideą projektu jest rewitalizacja budynku pod klastrer sztuki, pomysł polega na połączeniu historii przemysłowego obiektu i współczesnego kierunku sztuki.

Efektem decyzji projektowej jest zachowanie zabytkowego budynku i komina oraz przebudowa wraz z rozbudową części niemieszkalnej. Przestrzeń wewnętrzna w

zabytkowym budynku podzielona została na warsztat i część administracyjną zgodnie z nowoczesnymi normami przeciwpożarowymi i ewakuacyjnymi. Zmieniło się położenie schodów (w tym ewakuacyjnych), dodano windy (II. 2).

Od strony podwórza budynku, na miejscu wyburzonych starych budynków, zbudowano nową część klastra sztuki, używając nowoczesnym materiałów.

Funkcjonalne zagospodarowanie przestrzenne rozwiązano w następujący sposób: w piwnicy, gdzie pozwalają na to warunki techniczne i geologiczne, znajdują się pomieszczenia techniczne i magazynowe; pierwsze piętro jest przeznaczone na rozwój małych firm, na funkcję handlową i zmienną przestrzeń eventową; drugie piętro zajmuje ekspozycja, trzecie piętro - eventy i przestrzeń gastronomiczna. Z tyłu, po przeciwnej stronie ulicy, znajduje się płaszczyzna do coworkingu na 280 miejsc z pełnym zestawem odpowiednich funkcji.

Pierwsze piętro budynku zwraca uwagę przemysłowym charakterem obiektu i wzmacnia relacje z historyczną przeszłością. Komin fabryczny jest ozdobiony malowidłami w stylu sztuki ulicznej i jest też wyrazem klastra sztuki dla potrzeb młodych twórczych artystów.

\section{WNIOSKI}

Należy zatem zauważyć, że zmiany społeczno-polityczne we współczesnym społeczeństwie doprowadziły do rewizji systemu wartości estetycznych i kulturowych, zmieniły stosunek do samej sztuki i architektury. Powstanie innowacyjnego, wielopiętrowego budynku, tzw. klastra sztuki, gdzie połączono architekturę i sztukę, jest właśnie świadectwem takich zmian.

Trzeba zwrócić uwagę na bezpośredni wpływ klastrów sztuki zajmujących duży obszar przedsiębiorstw przemysłowych i będących malowidłami ściennymi na fasadach budynków, na transformację środowiska miejskiego. Mają one także wpływ ideologiczny, ponieważ są one zaprojektowane z myślą o wyrażeniu pogladów wielu osób. 
Podstawowe zasady rewitalizacji nierentownych obiektów przemysłowych w ramach klastrów sztuki są następujące:

- zasada gentryfikacji okolicznych obszarów;

- zasada nowoczesnego kształtowania przestrzeni na podstawie wprowadzenia funkcji coworkingowych;

- zasada otwartych galerii - przestrzenie otwarte, warsztaty coachingowe, okienka handlowe i rozrywkowe, przestrzenie sztuki;

- zasada kontrastu zachowanego wyglądu i innowacyjnej treści funkcjonalnej.

Jak wynika z dotychczasowego doświadczenia legalizacji sztuki ulicznej i tworzenia klastrów sztuki, takim działaniom towarzyszy zmniejszenie przestępczości na obszarach miast, w których się znajdują.

Praca napisana pod kierownictwem naukowym dra hab. prof. Mykolaja Dyomina 


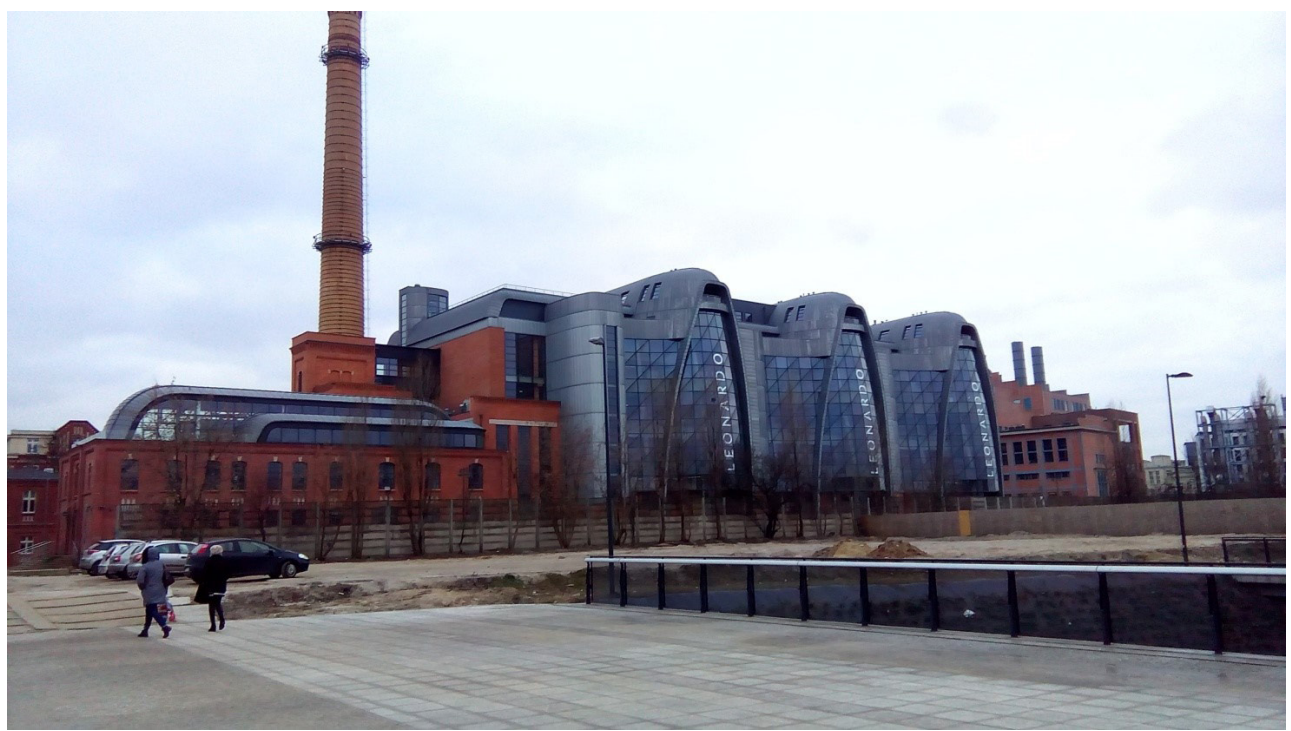

II. 1. EC1 Łódź koło Dworca Kolejowego Łódź Fabryczna (fot. O. Iwaszko 2018)

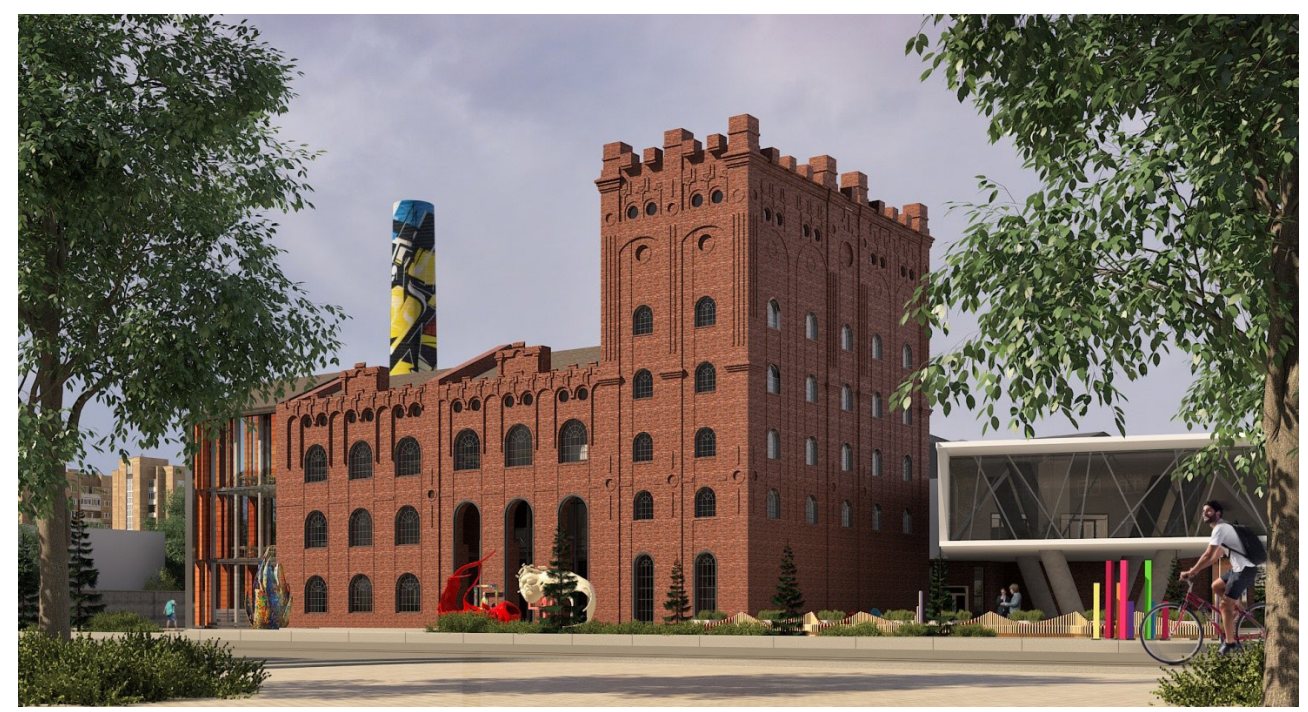

II. 2. Projekt magisterski O. Iwaszki transformacji browaru Richertowego pod klaster sztuki, 2018 


\section{BIBLIOGRAFIA}

Antonova A.A., Art-Klastery Kak Prostranstvo Dla Razvitiya Kulturnogo Potencyala Goroda, $\checkmark$ mirye nauki i iskusstva: voprosy filologyi, iskusstvovyedyeniya i kulturologyi: sb. st. Po mater. XLVII myezhdunar. naytch. konf.Nr 4(47), SibAK, Novosibirsk 2015.

Arkhitektura promyshlennyh predpryiatyi, zdanyi i soruzhenyi, N.N Kima (ed.), Stroyizdat, Moskva 1990.

Glazytchev W., Gorodskaya sreda. Tekhnologya razvitya: Nastolnaya kniga. M., Izdatelstvo Ladya, 1995.

Makarova K., Postindustryalism, dzhentrifikacya i transformacya gorodskogo prostranstva v sovryemyennoyi Moskvye, Nyeprikosnovennyi zapas, 2010.

Tykulov D., Fabriki prevrashtchayutsya v art - klastery, http://www.irn.ru/articles/31677. html (dostęp: 01.03.2015).

Fedotova N., Kreativniy klaster v kontekstye sockulturnyh problem regyiona, Bserosiyskaya nautchno-praktitcheskaya konferencya "Socyokulturnoye prostranstvo sovryemyennoy Rossiy: vyzovy XXI vyeka" : materyaly nautch. Konferenc, Knizhnyi dom "Librokom", 2013, 59-68.

Fyedotova N., Vectory regyonalnoy kulturnoy politiki v sfyerye kapitalizacyi kultury, Trudy Sankt-Petersburgskogo gosudarstvyennogo universiteta kyltury i uskusstv, Tom 199, 2013, 17-33. 